\title{
Are hospital staff aware of the economic benefits of employing people with disabilities?
}

\section{Czy zatrudnianie osób niepełnosprawnych wpływa na bilans ekonomiczny szpitala w świadomości jego pracowników?}

\author{
Małgorzata M. Machaj' ${ }^{1}$ Jacek Lorkowski², Ireneusz Kotela ${ }^{2,3}$ \\ 'Department of Administration and Human Resources, Central Clinical Hospital of the Ministry of the Interior, Warsaw, Poland \\ Head of the Department: Małgorzata Machaj PhD \\ 2Department of Orthopedics and Traumatology, Central Clinical Hospital of the Ministry of the Interior, Warsaw, Poland \\ Head of the Department: Prof. Ireneusz Kotela MD, PhD \\ 3Department of Rehabilitation in Disease of the Locomotor, Institute of Physiotherapy, Faculty of Medicine and Health Science, \\ Jan Kochanowski University, Kielce, Poland \\ Head of the Department: Prof. Ireneusz Kotela MD, PhD
}

Key words: disability, employment of people with disabilities, disabled, financing.

Słowa kluczowe: niepełnosprawność, zatrudnienie osób niepełnosprawnych, niepełnosprawny, dofinansowanie.

\begin{abstract}
Introduction: One of the regulations governing employment on the open labour market is the Act for vocational and social rehabilitation and employment of people with disabilities, which defines disability in the context that it impacts upon a person's ability to work.

Aim of the research: To evaluate the level of hospital staff awareness of the financial impacts of employing people with disabilities at the Central Clinical Hospital of the Ministry of the Interior in Warsaw.

Material and methods: The sample and control groups consisted of people working at the hospital, comprising 247 individuals, including 194 women and 53 men, aged between 25 and 60 years. The sample group consisted of people with disabilities. The control group consisted of colleagues with disabilities, of both sexes, and of the same age range. There was also a separate sample group comprising 60 people from middle management and senior management. The sample and control groups were provided with a questionnaire about issues relating to the economic aspects of employing people with disabilities. The results were compared with data from the questionnaire for management and from hospital statistics. The methodology of mathematical statistics was used.

Results: Discrepancies were found between sample and control groups, and hospital statistics pertaining to people with disabilities as employees in terms of the burden placed on the business, such as sick leave, breaks from work in the general sense, additional leave, accessing specialist tests during working hours, and earnings, in particular reimbursement of the cost of workplace equipment and funding for salaries.

Conclusions: There is a significant degree of divergence between managers' and employees' notions of privileges for disabled workers and their actual scale. There is misunderstanding and lack of knowledge of the applicable provisions of the Act for the Vocational and Social Rehabilitation and Employment of People with Disabilities amongst a considerable portion of employees and managers.
\end{abstract}

\section{Streszczenie}

Wprowadzenie: Jednym z przepisów regulujących zatrudnienie na otwartym rynku pracy jest ustawa o rehabilitacji zawodowej i społecznej oraz zatrudnianiu osób niepełnosprawnych, która definiuje niepełnosprawność, skupiając się przede wszystkim na możliwości wykonywania pracy.

Cel pracy: Ocena świadomości efektów finansowych zatrudniania osób niepełnosprawnych w Centralnym Szpitalu Klinicznym MSW w Warszawie wśród pracowników szpitala.

Materiał i metody: Grupę badaną i kontrolną stanowiły osoby pracujące w szpitalu. Populacja badanych pracowników składała się z 247 osób, w tym z 194 kobiet i 53 mężczyzn, w wieku 25-60 lat. Grupę badaną stanowiły osoby niepełnosprawne, natomiast grupę kontrolną - współpracownicy osób niepełnosprawnych obojga płci i w analogicznym wieku. W odrębnej grupie znalazło się 60 osób z kadry zarządzającej średniego i wyższego szczebla. Dla grupy badanej i kontrolnej sporządzono ankietę dotyczącą problematyki uwarunkowań ekonomicznych zatrudniania osób niepełnosprawnych. Wyniki zestawiono $\mathrm{z}$ danymi z kwestionariusza dla kadry zarządzającej oraz danymi statystycznymi funkcjonowania szpitala. Zastosowano metody statystyki matematycznej. 
Wyniki: Stwierdzono rozbieżności pomiędzy grupa badaną a kontrolną oraz pomiędzy wynikami statystycznymi funkcjonowania szpitala w przypadku oceny osób niepełnosprawnych jako pracowników w zakresie obciążeń dla przedsiębiorstwa: korzystania ze zwolnień lekarskich, ogólnie pojętych przerw w pracy, dodatkowego urlopu, dostępności do badań specjalistycznych w godzinach pracy oraz zysków, w szczególności zwrotu kosztu wyposażenia stanowiska pracy i dofinansowania do wynagrodzeń.

Wnioski: Istnieje znacznego stopnia rozbieżność pomiędzy wyobrażeniami menadżerów i pracowników o przywilejach pracowników niepełnosprawnych a ich rzeczywistą skalą. Zauważono niezrozumienie i brak znajomości obowiązujących przepisów ustawy o rehabilitacji zawodowej i społecznej oraz zatrudnianiu osób niepełnosprawnych u znacznej części pracowników i menadżerów.

\section{Introduction}

One of the main tasks of social policy is to ensure adequate health care. In Poland, at the end of 2012, there were a total of 913 hospitals providing 188,800 beds for a total of 7.9 million patients per year; that means 49 beds per 10,000 members of the population, or one bed per 204 people. When compared to 2011, there was no significant change in the number of beds or the number of patients. The number of beds decreased by 176 , or $0.1 \%$, while the number of hospitalised people increased by $0.2 \%$, or 14,800 . Over the past eight years there has been a continued upward trend in the number of patients and a declining trend in the number of beds. Compared to 2005, the number of patients increased by $11 \%$, while the number of beds decreased by $5.1 \%$.

One of the regulations governing employment on the open labour market is the Act for vocational and social rehabilitation and employment of persons with disabilities, which defines disability in the context that it impacts upon a person's ability to work. Disability is a permanent or periodic inability to perform social roles because of permanent or long-term impairment of the body, in particular resulting in the inability to work [1].

\section{Aim of the research}

The aim of the study was to evaluate the level of hospital staff awareness of the financial impacts of employing people with disabilities at the Central Clinical Hospital of the Ministry of the Interior in Warsaw.

\section{Material and methods}

The sample and control groups consisted of people working at the Central Clinical Hospital of the Ministry of the Interior in Warsaw. The selection of both groups was random.

The sample group comprised 247 working individuals, including 194 (78\%) women and 53 (22\%) women. The subjects of the study were aged between 25 and 60 years, with an average age of 42.9 years. There was no statistically significant difference ( $p=0.22$, NS) between gender or perceptions of degree of disability.

Participation in the study was voluntary, coupled with the provision of anonymity. The age group con- sidered to be the most professionally active was identified for the purpose of deeper analysis. Both groups were comparable in terms of age, gender, and their positions.

Among the 247 respondents, 128 (51.8\%) employees indicated a lack of professional experience in healthcare centres, including $74(58.7 \%)$ of employees with disabilities, and 54 (44.6\%) of employees without disabilities. More than half of all respondents ( $n=139,56 \%)$ had been working at the hospital for at least 10 years, while the proportion of those without disabilities to those with disabilities was 78 : 61 (i.e. $64 \%$ without and $48 \%$ with).

With respect to the sample group of disabled people, it is important to note that the largest increase in employment at the hospital took place from 2011 to 2014 . Of those, $77.40 \%$ (14.90 FTE) had a mild degree of disability, $41.18 \%$ (1.75 FTE) had a significant degree of disability, and with a moderate degree of $31.02 \%$ (12.75 FTE) had a moderate degree of disability (Figure 1). Most of the people with disabilities (i.e. $81.36 \%$ ) are employed at the central unit in Warsaw, and $18.64 \%$ in external units.

The control group was selected randomly throughout the hospital from the same organisational units as the sample group, but without significant disabilities. The sample was selected so as to encompass all possible representative markers in the survey, i.e. 121 people, including 99 (81.8\%) women and $22(18.2 \%)$ men. The group had a statistically uniform character.

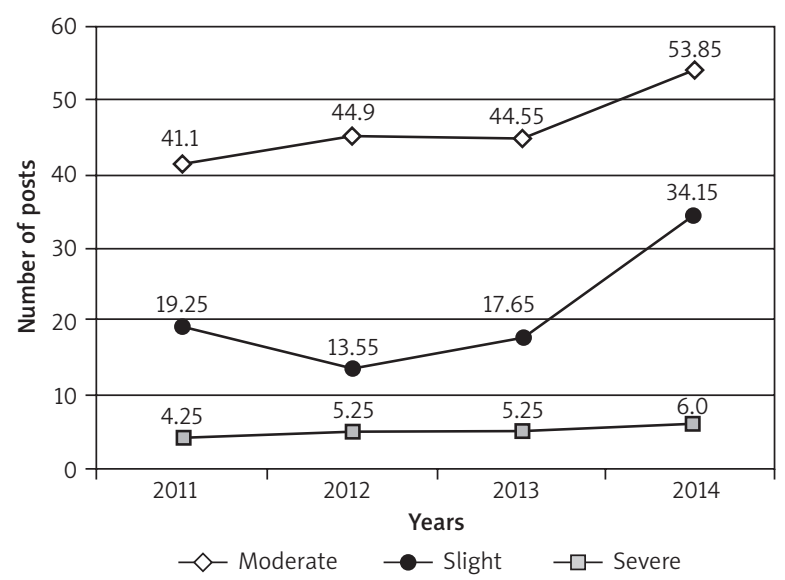

Figure 1. Number of employees in 2011-2014, taking into account the degree of disability 


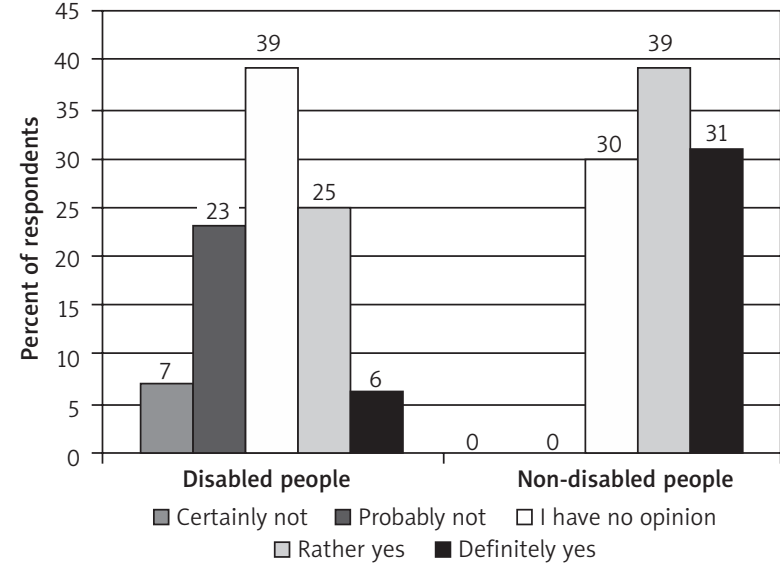

Figure 2. The opinion of the employees surveyed on the claim that workers with disabilities to not pose a burden on the organisation

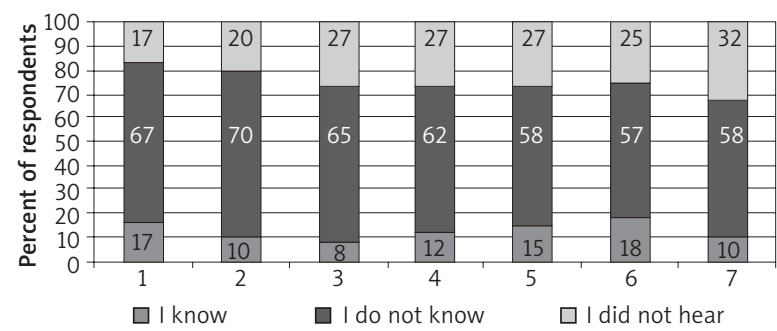

1. Grant for remuneration of employees with disabilities. 2. Funding for social security contributions of workers with disabilities. 3. Reimbursement of $60 \%$ of salary and compulsory social security contributions of new employees with disabilities. 4. Reimbursement of the costs of employing a disabled worker's assistant. 5. Reimbursement of the cost of adapting the workplace. 6. Reimbursement of workplace equipment. 7. Lowered monthly payments for PFRON.

Figure 3. Knowledge amongst management of the support for employers of people with disabilities

In addition, 60 people were tested amongst management, i.e. 39 (65\%) women and 21 (35\%) men. Forty-nine $(81.7 \%)$ had over 10 years of professional experience, 9 (15\%) had between 4 and 9 years, and $2(3.3 \%)$ had up to 3 years of service at the hospital.

The sample and control groups were provided with a questionnaire. The anonymous survey was specially developed with different sections for employees and employers. In the section for employees there were 25 main questions. The first block of questions had an introductory character and comprised questions regarding basic demographic data. The second block concerned the research issues proper and included a set of questions relating to the substantive scope, which were presented in a specific way.

The study included also middle- and senior-level managers. The part for managers contained 17 questions pertaining to knowledge and the ratio of employment of people with and without disabilities, the resulting economic impacts, and social conditions. The second block of questions assessed the subjective experience of respondents who had collaborated with people with disabilities. The degree of knowledge of various forms of support for employers in the open labour market was analysed. The question about respondents' knowledge of various forms of support for employers of people with disabilities was intended to compare the knowledge of people with and without disabilities, including managers, on the knowledge of certain provisions. The obtained results form part of the hospital's operational statistics.

\section{Statisical analysis}

Statistical descriptors were applied to a collected data set (variable). The normal distribution of the variable was tested using Lilliefors corrected version of the Kolmogorov-Smirnov test, as well as the ShapiroWilk test.

\section{Results}

An analysis of the 42 questions was conducted. Below are the answers to these questions including statistically significant differences between the sample and control groups. In the opinion of the surveyed employees $(n=37,15 \%)$, people with disabilities often take advantage of sick leave. This study did not confirm the cost of sick leave in 2014 for people with and without disabilities.

Only half of the employees surveyed ( $n=125,51 \%)$ indicated that they believed workers with disabilities do not pose a burden on an organisation. As much as $15 \%(n=37)$ of the surveyed workers presented a different opinion and indicated a belief that people with disabilities do pose a burden. Other staff $(n=85,34 \%)$ had no opinion on the issue. However, it is statistically significant $(p<0.001)$ that of these, a greater proportion of people without disabilities strongly felt that people with disabilities ( $7 \%$ vs. $0 \%$ ) or more ( $23 \%$ vs. $0 \%$ ) represented a burden on the organisation, while a greater proportion of people amongst workers with disabilities believed that people with disabilities definitely do not pose a burden on the organisation (31\% vs. 6\%) (Figure 2).

More than half of the employees surveyed $(n=$ $128,52 \%$ ) believed that, in accordance with applicable law, a person with disabilities (regardless of the degree of disability) is entitled to a 30-minute break at work, which is included in their working hours, for rehabilitation, exercise, or rest. Meanwhile, as much as $15 \%(n=36)$ of the employees surveyed believed the contrary. The remaining people $(n=83,34 \%)$ had no opinion on this issue.

Most of the employees surveyed ( $n=154,62 \%$ ) also believed that in accordance with applicable law, a disabled person with significant or moderate degrees of disability is entitled to an additional 10 working days of leave. The opposite belief was held by $5 \%$ $(n=12)$ of the surveyed employees. As much as one 
third of the respondents $(n=81,33 \%)$ had no opinion on the issue.

More than half of the employees surveyed $(n=129$, $52 \%)$ stated that, in accordance with applicable law, it was true that a disabled person had the opportunity to undergo 10 days of rehabilitation once a year. Only $5 \%(n=12)$ of the employees surveyed answered this question correctly. As much as $43 \%$ of patients $(n=106)$ had no opinion on the issue.

Forty percentage of employees surveyed $(n=100)$ believed that in accordance with applicable law, a disabled person (regardless of the degree of disability) had the opportunity to undergo specialised tests and treatments during working hours, if they could not be performed outside working hours. Only 15\% $(n=37)$ of the employees surveyed held the opposite view. As much as $45 \%(n=110)$ had no opinion on the issue.

Sixty-three percentage of managers $(n=38)$ did not know or had not heard of any form of support (Figure 3). Most people understood such support to mean reimbursement of costs of equipping the workplace $(n=11,18 \%)$, subsidies for salaries of disabled workers $(n=10,17 \%)$, and reimbursement of the costs of adapting the workplace $(n=9,15 \%)$.

There were no differences between the sample group and the control group, especially in regard to their responses on the following issues: the difference in the support provided by the supervisor/co-worker, appropriate adjustments of the work post, workplace regulations requiring mandatory employment of people with disabilities, and the lack of financial consequences for the employer for not employing people with disabilities.

\section{Discussion}

In Poland, the total expenditure on healthcare, i.e. current and capital expenditures in 2011, amounted to 105 billion PLN and accounted for $6.9 \%$ of Gross Domestic Product (7\% of GDP in 2010). In turn, current public expenditure on healthcare amounted to 69.2 billion PLN and accounted for $4.5 \%$ of GDP $(4.7 \%$ of GDP in 2010) [2, 3].

Financial management is a very important factor that influences the development of healthcare. Financial stability is one of the essential needs of each medical facility, and it still poses major challenges. Developing faultless financial strategy, and the introduction of new systems for billing, invoicing, and contracting of healthcare services is one way to improve finances in the healthcare sector.

Therefore, hospital managers should properly define the current needs of the organisation, make appropriate and timely decisions related to the current functioning of institutions and be able to anticipate needs and develop functional frameworks for the healthcare facility in the future [4]. Each plan must be flexible, dynamic, constantly reviewed, and adapted to existing conditions [5].
One of the purposes of our study was to achieve a flexible and dynamic verification of the employment policy at the Central Clinical Hospital of the Ministry of the Interior. It should be noted that approximately one third of respondents (33\%) declared that they possessed general knowledge of the rules that had an impact on the microeconomic situation of the hospital if people with disabilities were employed. However, the opinions expressed during the study confirm poor knowledge of the laws regarding the employment of people with disabilities [6].

Employment of workers with disabilities can provide financial benefits to annual profit and loss statements. The trend in employing workers with disabilities is a conscious policy of securing the employment of people with certified degrees of disability at the hospital. According to the study, employers gain measurable microeconomic financial benefits by doing so. Above all, this applies to the reduced payments that must be paid to the State Fund for the Rehabilitation of the Disabled for failing to meet the $6 \%$ quota for the number of people with disabilities employed. Employees at the Central Clinical Hospital of the Ministry of the Interior in Warsaw (CSK MSW), both with disabilities (82.6\%) and without (89.7\%), indicated that they "do not feel any difference" brought about by the special needs that may require the adaptation of work posts. An analysis of expenditure at the CSK MSW confirms the lack of additional increased spending on the creation of special posts.

The macroeconomic effects on the national economy can include increased revenue of GDP by reducing expenditure on social security benefits (pensions) paid to those with certified disability, as well as social benefits such as poverty reduction and a dependence on families or the state (as a result of people with disabilities being able to support themselves through income that is often higher than the social security payments). This has been confirmed by our findings. In 2013, compared with 2012, there was a 46,000 decrease in the number of people receiving a pension due to their inability to work $(1,075,000$ to $1,121,000)$ [7]. The cost of all disability benefits in Poland constitutes $4.9 \%$ of GDP per year [8]. Of the people with disabilities, two million are of working age [9].

When comparing the responses of employees and management, especially with regard to the types of disabilities that occur amongst workers, special attention needs to be paid to the relatively insufficient knowledge of management about their employees with disabilities in their organisational units. Specific studies have revealed a limited knowledge of the rules for hiring people with disabilities.

In particular, $49 \%$ of workers without disabilities felt that hiring people with disabilities posed a burden upon the employer. There was no awareness of the benefits such as reimbursement of workplace equipment costs. The lack of awareness of this aspect 
of hospital finances and the opportunity to develop it could be problematic.

Amongst the effects on the costs to employers, one can count the following: the impact of the costs of additional holidays for people with certified disabilities, the costs of participation in rehabilitation, additional time off work, and a reduction of the number of working hours to seven per day. In the opinion of $15 \%$ of employees surveyed, people with disabilities often take advantage of sick leave. However, no studies have confirmed the costs of sick leave in 2014 with respect to people with and without disabilities. According to the literature available, the overall costs of employing people with disabilities are not as high as indicated in the documentation relating to workplace operations on the open labour market [10].

The study did not confirm that higher costs were incurred as a result of employing people with disabilities when compared with non-disabled people at the analysed workplaces [11]. In particular, it did not confirm an increase in costs resulting from a temporary inability to work, higher volume of leave, additional downtime, or increased costs of workplace equipment. It did confirm similar performance output in equivalent jobs and the same levels of engagement amongst employees with and without disabilities. The results will help optimise economic solutions already in place, in order to achieve increased liquidity and sound human resource management. Given the above analysis, the Central Clinical Hospital of the Ministry of the Interior in Warsaw should continue to pursue a hiring policy consistent with those described. At the same time, it should implement a program for assessing the degree of satisfaction with employment and a training program for the equal treatment of employees.

\section{Conclusions}

There was a significant degree of divergence commonly demonstrated between managers' and employees' notions of the privileges for workers with disabilities and their actual scale. A large portion of employees and managers failed to recognise the opportunities to develop the business by obtaining funding for the development of posts for people with disabilities.

\section{Conflict of interest}

The authors declare no conflict of interest.

\section{References}

1. Ustawa o rehabilitacji zawodowej i społecznej oraz zatrudnianiu osób niepełnosprawnych z dnia 27 sierpnia 1997 roku (Dz. U. z 2011 roku, nr 127, poz. 721, art. 2 ust. 10.
2. Nałęcz S. Zdrowie i ochrona zdrowia. GUS Departament Badań Społecznych i Warunków Życia. Warszawa 2013; 119.

3. Jaworzyńska M. Planowanie i finansowanie w Zakładach Opieki Zdrowotnej. CeDeWu Sp. z o.o. Warszawa 2010; 25.

4. Jaworzyńska M. Planowanie finansowe $\mathrm{w}$ zakładach opieki zdrowotnej. CeDeWu Sp. z o.o. Warszawa 2010; 114-6.

5. Nowicki P, Pobrotyn P, Drobnik J, et al. Budżetowanie jako narzędzie wspomagające zarządzanie finansami w zakładzie opieki zdrowotnej. In: Wybrane zagadnienia zdrowia publicznego. Vol. 1: Nowoczesne narzędzia zarządzania w zakładach opieki zdrowotnej. Budżetowanie - controlling - outsourcing. Drobnik J, Kollbeka P (eds.) Continuo, Wrocław 2006; 7-29.

6. Opini BM. A review of the participation of disabled persons in the labour force: the Kenyan context. Disability and Society 2010; 25: 271-87.

7. ZUS. Departament Statystyki i Prognoz Aktuarialnych. Ważniejsze informacje z zakresu ubezpieczeń społecznych 2012. Available at: www.zus.pl/files/Wa\%C5\%BCniejsze\%20informacje\%20z\%20zakresu\%20ubezpiecze\%C5\%84\%20spo\%C5\%82ecznych $\% 202012 \% 20$ r.pdf - [30.03.2015].

8. Piętka-Kosińka K. Koszty niepełnosprawności. In: Instytucjonalne, zdrowotne determinanty niepełnosprawności. Golinowska S, Sowa A (eds). Instytut Pracy i Spraw Socjalnych, Warsaw 2012; 431.

9. Zgierska A. Osoby niepełnosprawne na rynku pracy. Główny Urząd Statystyczny, Warszawa 2011; 6-12.

10. Gartrell A. 'A frog in a well': the exclusion of disabled people from work in Cambodia. Disability and Society 2010; 25: 289-301.

11. Machaj M, Lorkowski J, Kotela I. Zarządzanie niepełnosprawnością w miejscu pracy - na przykładzie szpitali w Warszawie. Przegląd Medyczny Uniwersytetu Rzeszowskiego i Narodowego Instytutu Leków w Warszawie. Rzeszów 2014; 3: 262-74.

\section{Address for correspondence:}

Małgorzata M. Machaj PhD

Department of Administration and Human Resources Central Clinical Hospital of the Ministry of the Interior ul. Husarska 5, 02-489 Warsaw, Poland

Phone: +48500102635

E-mail: mmachaj1@wp.pl 